\title{
THE PERIGLACIAL VEGETATION IN FINNISH KARELIA
}

\author{
YRJÖ VASARI, ANNIKKI VASARI and KRISTOFFER BONDESTAM
}

\begin{abstract}
YRJÖ VASARI, ANNIKKI VASARI and KRISTOFFER BONDESTAM, 1997: The periglacial vegetation in Finnish Karelia. Bull. Geol. Soc. Finland 69, Part 1-2, 115-116.
\end{abstract}

Keywords: Periglacial vegetation, Finnish Karelia

Department of Ecology and Systematics, Division of Instruction in Swedish, Botanical Laboratory, P.O.Box 7, FIN-00014 University of Helsinki, Finland

The general features of the development of the periglacial vegetation in Finland were described already in the 1970 s by Donner (1971, 1978) and Hyvärinen (1971, 1972, 1973). Their descriptions were based on studies made in the Salpausselkä region in Karelia, where limnic deposits originating from the Late-glacial period afford a basis for reliable analyses.

According to them, an Artemisia-rich pollen zone, regularly found in the limnic bottom deposits represented the end of the Late-glacial. It ended ca. 10100-10000 B.P. and was followed by an at first gradual, then steep rise of Betula and successive maxima of the pollen of Rumex, Cyperaceae-Poaceae and Ericales and of the spores of Lycopodiales.

In 1990 a re-investigation was started of two sites, Koivusilta and Mustalampi, studied in the 1960 s by Repo and Tynni (1967, 1969). The three co-authors were joined for this new investigation by Geoffrey Lemdahl (a coleopterologist) from the University of Lund, and Kristiina
Eskonen (a diatomologist) from the University of Joensuu. Our intention was to specify the earlier results in greater detail with the help of new methods. The analyses of macroscopic remains were especially useful in providing a great deal of new information (Bondestam et al. 1994).

It became possible to distinguish several subphases in the periglacial vegetation. The Artemisia-rich pollen zone corresponded with a phase of open pioneer vegetation. This was then followed by a phase of rich fjell heath vegetation characterized by Dryas octopetala, Salix herbacea and Salix polaris. In the pollen diagram this phase corresponded with the maxima of Cyperaceae-Poaceae and Rumex. The beginning of the rise of the Betula pollen curve was caused by Betula nana, which, together with Ericales dwarf-shrubs, dominated a poorer type of fjell heath vegetation.

The Artemisia phase, which ended ca. 1015010100 B.P. along with the phase of the rich fjell 
heaths, is best regarded as belonging to the Lateglacial proper. The phase of dwarf-shrub heaths, which began ca. 9800-9400 B.P. with Betula nana as the dominant plant, evidently initiates the Holocene. This intermediate phase is likely to represent a continental facies in the Late-glacial/Holocene succession, corresponding with Empetrum-Juniperus facies further west. A few hundred radiocarbon years later (9400-9100 B.P.) this treeless vegetation was replaced by advancing light birch-aspen forests (Betula pendula, Betula pubescens and Populus tremula). Pine (Pinus sylvestris) also arrived at almost the same time.

\section{REFERENCES}

Bondestam, K., Vasari, A., Vasari, Y., Lemdahl, G. and Eskonen, K. (1994) Younger Dryas and Preboreal in Salpausselkä foreland, Finnish Karelia. In: Lotter, A.F. and Ammann, B. (eds); Festschrift
Gerhard Lang. Dissertationes Botanicae 234, 161206.

Donner, J.J. (1971) Towards a stratigraphical division of the Finnish Quaternary. Soc. Scient. Fennica, Comment. Phys.-Math. 41, 282-305.

Donner, J.J. (1978) The dating of the levels of the Baltic Ice Lake and the Salpausselkä moraines in South Finland. Soc. Scient. Fennica, Comment. Phys.-Math. 48, 11-38.

Hyvärinen, H. (1971) Two late Weichselian stratigraphical sites from the eastern foreland of the Salpausselkäs in Finland. Comment. Biol., Soc.Scient. Fennica 40, 1-12.

Hyvärinen, H. (1972) Flandrian regional pollen assemblage zones in eastern Finland. Comment. Biol., Soc. Scient. Fennica 59, 1-25.

Hyvärinen, H. (1973) The deglaciation history of eastern Fennoscandia - recent data from Finland. Boreas 2, 85-102.

Repo, R. and Tynni, R. (1967) Zur spät- und postglazialen Entwicklung im Ostteil des ersten Salpausselkä. C.R. Soc Géol. Finlande 39, 133-159.

Repo, R. and Tynni, R. (1969) Morphologisch-stratigraphische Grundzüge des östlichen SalpausselkäGebiets. Bull. Geol. Soc. Finland 41, 203-229. 